\title{
NUTRITION IN AGRICULTURAL DEVELOPMENT: The Case of Irrigated Rice Cultivation in West Kenya
}

\author{
RUDO NIEMEIJER, MARIAN GEUNS, TED KLIEST, VINCENT OGONDA \\ and JAN HOORWEG \\ African Studies Centre, Food and Nutritions Studies Programme, Leiden, \\ Netherlands
}

(Received August 27, 1987; in final form February 19, 1988)

\begin{abstract}
This study on the nutritional aspects of agricultural and rural development, examines the case of irrigated rice cultivation in Western Kenya. Large-scale irrigation schemes were established in the region two decades ago; in the past few years, paddy production by independent smallholders has been expanding rapidly. Nutrition surveys were conducted among four groups of farmers differing in degree of participation in and dependence on irrigated rice production. These include: non-rice growers, resident tenants at large-scale irrigation schemes, non-resident tenants at the large schemes who also farm sizeable plots of land elsewhere, and individual rice growers who have a similar combination of resources as the third group but who usually cultivate only small rice plots.

The observed differences in nutrition between the four groups appeared to be primarily related to diversity in available resources. The group with the most narrow resource base namely the resident tenants had the lowest food production for home consumption and the lowest average energy intake per consumption unit. This group also had the lowest food intake levels among young children and showed a higher incidence of stunting compared to children belonging to the other study groups. The nutritional differences among the remaining groups were much smaller but the nutritional status of the children of the non-resident tenants, the group with the widest resource base, proved the most favourable. The two remaining groups took an intermediate position in respect of diversity of resources as well as nutritional conditions.
\end{abstract}

KEY WORDS: agricultural and rural development, child nutrition, cereal production, food consumption, Kenya, large and small-scale irrigation, nutritional status, rice cultivation

\section{INTRODUCTION}

\section{Nutrition in Agricultural Development}

Since recent publications by the OAU (1981) and the World Bank (1981) there has been renewed attention directed towards the need to stimulate the agricultural sector in Sub-Saharan Africa and to increase the production of export crops and food crops. Suggested policy measures include attractive and stable pricing, improvements in marketing arrangements, credit facilities and extension services together with changes in farming practices. Essential changes in farming practices include the introduction of new crops and improved crop varieties, modern farming techniques and production methods, as well as alternative land tenure arrangements. Such measures, usually implemented through agricultural and rural development projects, invariably imply an accelerated transition from subsistence farming to market production.

Usually, the implicit assumption is that new crops and modern techniques leading to improved production automatically result in increased incomes and 
higher standards of living. However, this is not necessarily the case, as demonstrated by family nutrition, a major indicator of well being. Positive nutritional effects may indeed emanate from increased production. Higher output of food crops may result in increased food availability; alternatively, increases in production of commercial non-food commodities may generate higher incomes which can be used to secure nutritional needs. There is substantial evidence that increases in productivity are often realized at the expense of the nutritional situation of the farming population. Different studies point to various underlying economic, social and cultural factors ${ }^{\dagger}$ (Fleuret and Fleuret, 1980; Kennedy and Pinstrup-Andersen, 1983; Lunven, 1982).

Development projects often fail to benefit all households in a given region because of their concentration on progressive farmers or because of one-sided attention to fertile or easily accessible areas. Wealthy farmers, moreover, often succeed in monopolizing agro-support services which may lead to a deterioration of the situation among the poorer segments of the farming population. Income gains from commercial crops often fall short of compensating for the loss of subsistence output, while project planners frequently fail to evaluate subsistence output accurately, and underestimate the financial costs of new agricultural techniques as well as the costs of the required household labour. Farmers are furthermore faced with low producer prices as a result of adverse price trends in the world market and heavy taxation and inefficient marketing procedures in many countries.

In addition, commercialization of agriculture often puts an increased demand on female household labour thereby substantially reducing the time and effort that can be devoted to nutrition. This may lead to a lower time allocation for food crop cultivation but also to a diminished attention for food storage and food preparation, supervision of intra-family food distribution, child feeding (including breastfeeding) and general child care. Commercialization often causes a risky narrowing of the crop mix and a substitution of subsistence output and on-farm food stocks by monetary income and food purchases. Cash incomes from commercial farming tend to peak during certain periods of the year, and they are generally paid to the (male) head of the household and are frequently used for needs other than the direct food requirements of the family. Furthermore, patterns of food consumption are likely to change once most food has to be purchased. New and prepacked foods are generally more expensive and often do not contribute to balanced diets.

There is a need to introduce nutritional objectives in agricultural and rural development projects and programmes (FAO, 1982; Pacey and Payne, 1985). However, methods to assess project needs with respect to nutrition have to be further developed, while in general more knowledge is required about the nutritional effects of agriculture change and rural development ${ }^{\ddagger}$. The study presented here concerns the nutritional implications of commercial rice production on large-scale irrigation schemes in West Kenya. The study was carried out in early 1984, and a report with recommendations has been submitted to the Kenyan authorities (Niemeijer et al., 1985).

\footnotetext{
${ }^{+}$Martin T.H. Nutritional consequences of agricultural development projects: A survey of the evidence. Paper submitted to the 10th Session of the ACC Sub-Committee on Nutrition, F.A.O. Rome, 1984.

₹Pinstrup-Anderson, P. Nutritional consequences of agricultural projects: Conceptual relationships and assessment approaches. Worid Bank Staff Working Paper No. 456. Washington D.C., 1983.
} 


\section{Irrigated Agriculture in Kenya}

Kenya faces the problem of securing an adequate food supply for its fast increasing population (McCarthy and Mwangi, 1979; Senga, Faruqee and Ateng, 1981; World Bank, 1983; Kliest, 1985). Already, pressure on arable land is high, and future increases in agricultural production will depend on the possibilities of increasing yield levels per ha, as well as bringing unused, often marginal lands under cultivation (Mwangi, 1981; Republic of Kenya, 1984). Improved water management, notably irrigation is one of the means to increase agricultural production and Kenya's potential for irrigated agriculture is quite substantial (World Bank, 1983). Over the past two decades the National Irrigation Board (N.I.B.) has established several large-scale schemes for the production of rice, sugar cane, and cotton in different parts of the country (Republic of Kenya, 1984). Government support is also given to the development of low-cost, small irrigation projects.

Large irrigation schemes for the production of rice were started in Central, Nyanza and Western Province (NIB, 1982). These schemes are centrally managed and reserved for mono-cropping of paddy by tenant-farmers who have to adhere to strict farm regulations. The management of each scheme is responsible for land preparation, and provides farmers with fixed quantities of agricultural inputs. The N.I.B. handles the marketing of the produce and after subtraction of the costs of land preparation, inputs and marketing, the proceeds are paid in cash to the farmers. Each tenant is allowed to retain a fixed quantity $(10 \%)$ of his total paddy production for home consumption.

In several parts of Kenya, irrigation projects have been started by smallholder farmers at their own initiative without much direct government involvement. In contrast to the tenants at the large irrigation projects, the farmers participating in so-called small-scale irrigation enjoy a greater freedom in decision-making and choice of crop. In recent years, Western Kenya has witnessed a rapid growth of these schemes, which are mainly producing rice.

The experiences with the large-scale schemes to date have been mixed. Generally, output and income levels have been below expectation, although there are differences in the degree of success (NIB, 1982; Ruigu, 1987). Moreover, the nutritional conditions at some of the schemes, for example, the Mwea and Ahero rice schemes, have caused concern (Korte, 1969). Systematic information as to the specific conditions under which nutritional problems do arise, however, are lacking and this study aims to specify these conditions by comparing different kinds of participation in irrigated rice cultivation in the Kano Plain in Western Kenya.

The N.I.B. has established two large irrigation projects in Western Kenya: Ahero Pilot Scheme (1969) and West Kano Pilot Scheme (1976). They cover a total area of 4,800 ha out of which 840 ha is presently cultivated by 519 tenants in Ahero; while 553 tenants farm 880 ha in West Kano. In both schemes the area of irrigated land allocated per farming household is $1.6 \mathrm{ha}$. In Ahero, all irrigated farm land is used for paddy cultivation, in West Kano it is equally divided between paddy and sugar cane production. The average annual income from rice and sugar cane is in the range of 3,500 to 5,000 Ksh per farmer (Kliest, 1984).

Besides cultivating irrigated crops, many tenants also grow rainfed crops on 'non-scheme land', usually the small area around the house but also larger plots outside the schemes. Substantial differences exist with respect to access to rainfed farmland. Some tenants dispose of relatively large plots, others have to rely on 
irrigated land within the scheme only ${ }^{\dagger}$. Initially, all tenants were obliged to live in designated villages within the schemes, later they were allowed to take up residence outside the scheme and still retain their scheme plot. Nowadays, the tenants can be distinguished in a category of 'resident tenants' living in the schemes with none or a relatively limited amount of land outside the schemes, and a group of 'non-resident tenants' who live outside the schemes and who generally avail of more sizeable tracts of non-scheme land. Depending on the scheme, an estimated 30 to 50 per cent of all tenants belong to the latter category (Sterkenburg, Brandt and Beinum, 1982).

As early as the 1930's, smallholder farmers living in the area bordering Lake Victoria spontaneously engaged in the cultivation of irrigated rice. Severe floods and the rise of the lake in the early 1960's destroyed a substantial part of the irrigated land and rice production declined. From the late 1960's onwards, however, irrigated rice cultivation picked up again, probably as a result of demonstration effects of the two large-scale schemes and relatively high and stable producer prices for paddy. Currently smallholder paddy production in the area is expanding rapidly. ${ }^{\ddagger}$. The crop is chiefly produced for cash purposes, but growers also use small quantities for home consumption. Production takes place in smallholder schemes which are started by the local farmers themselves, each of them individually farming a small or large private or rented plot. The water distribution within the scheme is commonly controlled by farmers' committees.

\section{METHOD}

\section{Design}

The study aimed to compare categories of farming families differing in terms of their participation in irrigated rice cultivation. Two study groups consist of tenants at large irrigation schemes: tenants living in the scheme villages (resident tenants; $\mathrm{N}=83$ ), and tenants living outside the scheme (non-resident tenants; $N=64$ ). The third category includes individual rice growers involved in small irrigation schemes $(\mathrm{N}=54)$. For purposes of comparison, a fourth group of farmers not connected with rice production in any of the above ways was included $(\mathrm{N}=134)$. Households were sampled from five geographical locations: Ahero and West Kano Schemes and the three sub-locations of Kochieng, Kamagaga and Kombura. For a more detailed description of the study area and the sampling procedures, see Niemeijer et al., 1985. The survey covered the period March and April 1984 which is the season of the long rains prior to the harvest of the main staple foods, maize and sorghum, and

${ }^{2} A$ number of tenants had access to land in the Kano Plain prior to their settlement at the schemes, others managed to acquire land outside the schemes at a later stage.

FIn 1980 , smallholders planted an estimated total of 135 ha with paddy. Three years later this area had almost tripled, and by the end of 1985 had reportedly rocketed to 880 ha, involving more than 2000 households (Ministry of Agriculture: Progress Report on Smallholder Rice Development, District Rice Officer, Kisumu, 1981; Ministry of Agriculture: Annual Reports 1982 and 1983, District Rice Officer, Kisumu; Ministry of Agriculture: Some Aspects of Smallholder Rice Development, Provincial Irrigation Unit. Note MAC/510. Kisumu, 1986.) 
is the time when on-farm foodstocks are usually at their lowest level and nutrition problems most manifest'.

The population of the study area is quite homogeneous, the large majority being of Luo ethnic origin. Because of the inclination of families in one compound to share economic resources and to have mutual cooking and eating arrangements, compounds were taken as the sampling unit. A compound may consist of one or more houses, accommodate one or more families and, independently, feature one or more kitchens. The survey included a total of 335 compounds, numbering 419 children aged 0-47 months; 615 children, aged 4-10 years; 475 children, aged 11 16 years and 1286 adults.

\section{Data}

Crop cultivation, livestock rearing and income from off-farm activities are the three main economic resources of the rural population in the Kano Plain. The livelihood of the smallholder farming families covered by the study is usually based on a combination of these resources while, in respect of crop cultivation, the production of food crops is often combined with that of cash crops. Because of the constraints of a relatively modest survey such as this, with single-visit interviews, the economic resources of the farming families had to be estimated indirectly. Indicators were sought that provided reliable information, yet did not touch on sensitive subjects such as the remittances sent by migrant labourers and the exact number of cattle owned by the households. Agricultural production was assessed by means of interviews regarding the acreage planted with cash crops (rice, sugar cane and cotton) and food crops (cereals, pulses, and roots and tubers) during the long and short rain seasons of 1983/1984 and the quantities harvested. No attempt was made to estimate the total acreage in terms of fallow land and access to common grazıng land. Involvement in livestock keeping and off-farm employment was approximated with the help of simple indicators, namely the presence of a cattle pen, and whether there were any migrant workers in the household, without further attempts to quantify the actual income from these activities.

Food consumption was assessed by two recall methods: a recall of all food prepared and consumed in the compound during the day prior to the interview, and a 24-hour recall of the quantities of food consumed by individual children, aged 6-47 months, also for the previous day.

The recall of compound consumption was collected for each kitchen within the compound and included all the foods and drinks prepared in the course of the previous day. The women involved in the preparation were asked to indicate the volumes of the different ingredients used, as well as the total volume of the prepared dish. The volume of any left-overs was separately estimated and subtracted. All volumes were converted into the corresponding weights using a conversion table, based on observations made before the start of the survey. The estimates of energy and protein intake are expressed as intakes per consumption unit. (The number of consumption units in a compound equals the number of

In the ldrge irrigation schemes rice is planted and harvested according to a rotational pattern so that different tenants harvest at different times of the year The individual rice growers tend to plant when labour is avalable, and the main rice harvest of these farmers had been in the period NovemberDecember 1983 
adults increased with the number of children converted into adult equivalents $\left.{ }^{\dagger}\right)$.

Individual dietary recalls were collected for all children within the 6-47 month age bracket. Respondents were asked about the foods and drinks consumed by the child in the course of the previous day and night while it was also recorded whether the child was still given the breast or not. $\ddagger$. The portions were estimated with the help of the cup or plate which had been used by the child. The total weight of the cooked dish, as well as the weight of each ingredient was estimated using standard recipes that had been collected before the survey. For both recall methods the food table by Platt (1962) was used to calculate the energy and nutrient content of the foods.

Anthropometry included the measures commonly used in nutrition studies: weight, height and mid-upper arm circumference. Anthropometric data were collected for all children aged between 6 months and 11 years, as well as for adult women. (The presentation of results in this paper will be limited to children, aged 6-47 months). For the children under the age of two years a SALTER 235 scale was used (max. $25 \mathrm{~kg}$. with an accuracy of $100 \mathrm{grs}$.). Otherwise weights were measured with a TERRAILLON digital scale (max. $135 \mathrm{~kg}$. with an accuracy of 200 grs.). The height of children under two years was measured with a portable length board with a fixed headrest and a moveable footrest. The children were measured in supine position. Older children were measured standing straight with their backs against a portable pole with a sliding headrest. Mid-upper arm circumference was measured with an ordinary household measuring tape. All anthropometric measurements were expressed in terms of international reference values: height-for-age, weight-for-height, weight-for-age and mac-for-age. With the exception of mac-for-age which was calculated on the basis of the tables by Jelliffe (1966), all indices were calculated using the WHO reference population (WHO, 1983).

\section{RESULTS}

The present article contains an analysis by study-condition; a discussion of the general findings regarding dietary patterns and nutritional status of young children will be presented elsewheres. The presentation of the survey results below starts with background information on the living conditions of the farming families followed by a comparison of the resource base, food production and food availability for the households in the different study conditions. This is followed by a presentation of the findings with respect to food consumption and nutritional status.

\footnotetext{
+Conversion factors are based on the FAO/WHO (1974) recommended energy intakes for different age groups. For instance, the number of consumption units for a compound comprising one adult and two children under five years is $2.0(1.0+0.5+0.5)$.

₹The actual amounts of breastmilk were not measured. Instead the daily quantities were estimated using figures for Akamba children reported by Steenbergen et al. (1984). These figures were included in the individual calculations of the energy intake per kg. bodyweight of young children (Figure 2).

§Niemeijer R., M. Geuns and J. Hoorweg (in preparation). Child Nutrition in the Pre-Harvest Season: Food Intake and Nutritional Status of Luo Pre-School Children in Nyanza Province, Kenya.
} 
TABLE I

Housing conditions of rice farmers in West Kenya

\begin{tabular}{|c|c|c|c|c|c|}
\hline & $\begin{array}{l}\text { Non- } \\
\text { Rice } \\
\text { Growers } \\
(\mathrm{N}=134)\end{array}$ & $\begin{array}{l}\text { Individual } \\
\text { Rice } \\
\text { Growers } \\
(\mathrm{N}=54)\end{array}$ & $\begin{array}{l}\text { Non- } \\
\text { Resident } \\
\text { Tenants } \\
(\mathrm{N}=64)\end{array}$ & $\begin{array}{l}\text { Resident } \\
\text { Tenants } \\
(\mathrm{N}=83)\end{array}$ & $\begin{array}{c}\text { Total } \\
(\mathrm{N}=335)\end{array}$ \\
\hline $\begin{array}{l}\text { Average number of } \\
\text { Houses/Compound } \\
\text { Persons/Compound }\end{array}$ & $\begin{array}{l}2.8 \\
7.9\end{array}$ & $\begin{array}{l}2.9 \\
8.8\end{array}$ & $\begin{array}{r}3.1 \\
10.3\end{array}$ & $\begin{array}{l}1.8 \\
7.3\end{array}$ & $\begin{array}{l}2.6 \\
8.4\end{array}$ \\
\hline $\begin{array}{l}\text { Houses with } \\
\text { Roof. metal sheet }(\%) \\
\text { Walls, cement/block }(\%)\end{array}$ & $\begin{array}{r}49 \\
6\end{array}$ & $\begin{array}{r}28 \\
4\end{array}$ & $\begin{array}{l}69 \\
11\end{array}$ & $\begin{array}{l}86 \\
24\end{array}$ & $\begin{array}{l}58 \\
11\end{array}$ \\
\hline $\begin{array}{l}\text { Compounds with } \\
\text { Latrne }(\%) \\
\text { Improved water source } \\
\text { during wet season }(\%)\end{array}$ & 72 & 54 & 94 & 92 & $\begin{array}{l}78 \\
37\end{array}$ \\
\hline
\end{tabular}

\section{Living Conditions and Sanitation}

The average compound numbered 2.6 houses with a corresponding number of 8.4 persons per compound (Table I). The number of residential structures was lowest among the group of resident tenants because standard housing was provided at the schemes and the possibilities to build additional houses are restricted. The tenants living outside the schemes had much greater freedom in this respect. Consequently, they availed themselves of more houses and also had the largest number of people per compound. The resident-tenant families, on the other hand, were comparatively small in size, while the two other groups were somewhere in between. In more than half the compounds, the main house had a corrugated iron roof. Walls plastered with cement, or constructed of concrete blocks were far less common. The quality of the houses in the large irrigation schemes (resident tenants) compared favourably to that in the other study conditions.

Nearly all tenant households had a latrine and there was no difference in this respect between the tenants living at the schemes and those living elsewhere. The households of the two other groups less often availed themselves of a latrine and this was especially the case among the individual rice growers. Less than half the compounds used improved sources of drinking water in the current (wet) season. The N.I.B. tenants more often used improved water sources irrespective whether they are living inside or outside the schemes.

\section{Resource Base}

Rice was the dominant cash crop followed by sugar cane, whereas cotton was relatively unimportant (Table II). The area planted with cash crops was largest among the N.I.B. tenants. Among the individual rice growers the area under paddy averaged less than 1 acre; sugar cane and cotton were of minor importance. The farmers not growing rice largely concentrated on sugar cane production for their cash farm income.

The average food crop area (rainfed maize and sorghum) per compound varied considerably between the different study groups. The area planted with food crops 
TABLE II

Resource base of rice farmers in West Kenya

\begin{tabular}{|c|c|c|c|c|c|}
\hline & $\begin{array}{c}\text { Non- } \\
\text { Rice } \\
\text { Growers } \\
(\mathrm{N}=134)\end{array}$ & $\begin{array}{l}\text { Individual } \\
\text { Rice } \\
\text { Growers } \\
(\mathrm{N}=54)\end{array}$ & $\begin{array}{l}\text { Non- } \\
\text { Resident } \\
\text { Tenants } \\
(\mathrm{N}=64)\end{array}$ & $\begin{array}{l}\text { Resident } \\
\text { Tenants } \\
(\mathrm{N}=83)\end{array}$ & $\begin{array}{c}\text { Total } \\
(\mathrm{N}=335)\end{array}$ \\
\hline Acreaged under Cash Crops & 0.6 & 1.0 & 4.0 & 4.0 & 2.2 \\
\hline Rtce & - & 0.8 & 3.4 & 3.3 & 1.6 \\
\hline Sugar Cane & 0.5 & 0.2 & 0.5 & 0.7 & 0.5 \\
\hline Cotton & 0.1 & $<0.1$ & 0.1 & & 0.1 \\
\hline Acreage $^{\mathfrak{b}}$ under Maize and & & & & & \\
\hline Sorghum & 2.2 & 2.5 & 1.9 & 1.1 & 1.9 \\
\hline Presence of Cattle (\%) & 38 & 41 & 31 & 8 & 30 \\
\hline No. of Migrant Workers & 0.8 & 0.8 & 0.6 & 0.1 & 0.6 \\
\hline
\end{tabular}

aRice: Area harvested during past 12 months

Sugar Cane: Area under crop at the time of the survey

Cotton: Area planted during 1983

hArea planted during 1983

'As indicated by presence of a cattle pen in the compound

was smallest among the resident-tenants at the large schemes ${ }^{\dagger}$ as a result of the limited availability of farm land outside the schemes to these farmers. For the three remaining study groups the average area per compound under rainfed cereals was roughly the same, although the individual rice growers tended to have the largest area under rainfed crops.

In addition to food and cash crop production, stock raising played an important role in the economy of the originally pastoralist Luo farming families in the Kano Plain. A survey among farming households in a nearby sub-location calculated that livestock rearing contributed more than $50 \%$ of total farming income, although this seems a rather high estimate (N.I.B, 1981). Among the four study groups, the individual rice growers and the non-rice growers appeared to be more involved in livestock rearing than the two other groups. The resident tenants especially appeared to keep cows less often, undoubtedly due to the fact that the N.I.B. did not allow cattle to be kept inside the schemes.

Many households in the Kano Plain supplement their subsistence and monetary farm income with off-farm activities. Because of the limited opportunities for nonagricultural employment in the area, off-farming employment usually takes the form of migrant labour. The amount of cash involved is difficult to estimate. Remittances depend on the relationship between the migrant and his family, the frequency of contact and the net income earned. All but very few of the migrants were heads of family and they can be expected to remit money for improved housing, furniture, schoolfees, clothing and to buy food in times of scarcity. Not all the farming families in the Kano Plain are involved in labour migration. There were virtually no migrant workers in the households of resident tenants, in contrast to the three other groups, and this will have consequences for the inflow of remittances among this particular group.

${ }^{t}$ In practice very few farmers did plant annual crops during the short rains and the quantities harvested were negligible. Figures therefore rather reflect the 'long rains' acreages and harvests. 
TABLE III

Cereal production of nce farmers in West Kenya (kg)

\begin{tabular}{lccccc}
\hline & $\begin{array}{c}\text { Non- } \\
\text { Rice } \\
\text { Growers } \\
(\mathrm{N}=134)\end{array}$ & $\begin{array}{c}\text { Individual } \\
\text { Rice } \\
\text { Growers } \\
(\mathrm{N}=54)\end{array}$ & $\begin{array}{c}\text { Non- } \\
\text { Resident } \\
\text { Tenants } \\
(\mathrm{N}=64)\end{array}$ & $\begin{array}{c}\text { Resident } \\
\text { Tenants }\end{array}$ & Total \\
\hline $\mathrm{N}=83)$ & $(\mathrm{N}=335)$ \\
\hline $\begin{array}{l}\text { Marze and Sorghum } \\
\text { Rice }^{\mathrm{b}}\end{array}$ & 378 & $\begin{array}{c}315 \\
992\end{array}$ & $\begin{array}{c}261 \\
5,000 \\
(504)\end{array}$ & $\begin{array}{c}5,112 \\
(240)\end{array}$ & - \\
\hline
\end{tabular}

aPenod of 12 months, March 1983-March 1984

bListed in brackets are the estumated amounts of paddy retaned for home consumption

In summary the non-resident tenants had the most diversified resource base. They combined four acres under cash crops with consıderable participation in other economic activities. It is difficult to say whether their income is also higher than that of the individual rice growers and the non-rice growers, as this depends on the profitability of livestock raising and off-farm employment compared to rice cultivation. The individual rice growers who derived considerably less income from cash crops participated more in the two latter activities while also growing more food crops. The resident tenants however had a narrow resource base and depended almost totally on income earned from cash crops.

The results in the above section have been presented on a household basis and not per capita because the latter way of expressing resource data has certain

FIGURE I Cereal production for home consumption among nice farmers in West Kenya (Expressed as number of consumption days/consumption unit)

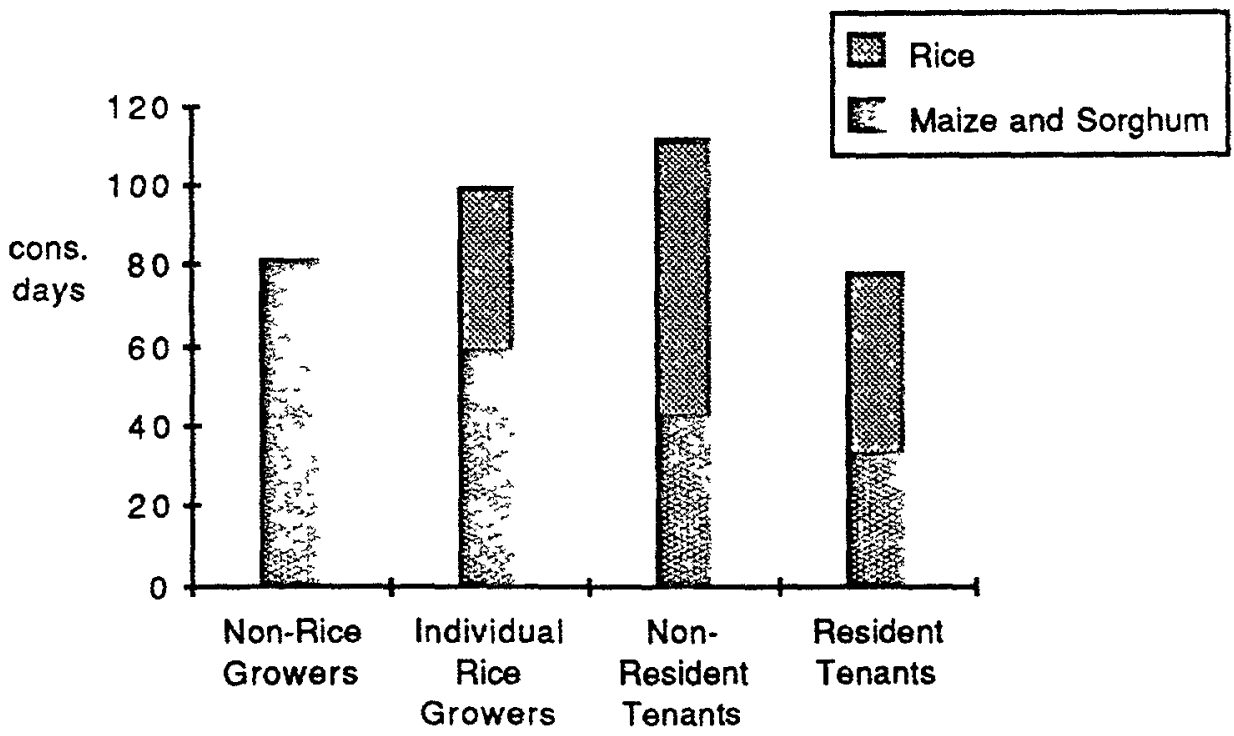


disadvantages ${ }^{\dagger}$. In the next section on food availability and food consumption, however, household size will be taken into account.

\section{Agricultural Production and Food A vailability}

Maize and, to a lesser extent, sorghum were the main staple foods grown by the smallholders of the Kano Plain. The output of these crops reported by the various categories of farmers during the $1: 83$ cropping season is shown in Table III. Both the resident and the non-resident tenants realized a smaller output compared to the other two groups which is expected due to the lower acreage of food crops that was reportedly planted. The disappointing harvest of 1983 caused by adverse weather conditions, resulted in very limited maize and sorghum sales, and farmers reported that virtually the total output was kept for home consumption. As regards rice production, the two groups of N.I.B. tenants realized comparable output levels, averaging about 63 bags or $5,000 \mathrm{~kg}$ per compound, whereas the individual rice growers harvested an average of $12 \mathrm{bags}(960 \mathrm{~kg})^{\ddagger}$. Although rice is primarily produced for cash purposes, farmers keep a certain proportion of their output for other purposes. Table III also presents the estimates of the quantities of rice used for home consumption, i.e. the proportion of the total output retained after delivery to the scheme, payment in kind to agricultural labourers and sales in the local markets. $\$$

Figure 1 shows the staple food output and the quantity of rice retained for home consumption converted into the estimated number of days that these home produced cereals sufficed to feed the compound residents. ${ }^{\text {tw }}$. The figures point at a relatively low food availability among all smallholders of the Kano Plain, about 50 to 60 days on average for the main staple foods maize and sorghum. The availability of maize and sorghum was especially low among the resident tenants. Farmers not growing rice obviously secured the largest quantities of maize and sorghum for home consumption. Nevertheless, their total maize and sorghum output during 1983 still covered only 80 consumption days. The quantity of rice for home consumption was highest among the non-resident tenants covering almost 70 days. Corresponding figures for the individual rice growers and resident tenants were 40 and 46 days, respectively.

Taken together, home produced cereals cover consumption for a period of almost 4 months for the group of non-resident tenants. Among the resident tenants

The relationship between available resources and number of people in the household is complex. More persons certainly means more mouths to feed, and in that sense lack of resources can act as a limiting factor on household size. However, more people can also mean more available labour and thus more income.

FThese figures reflect an average yield level of $3,375 \mathrm{~kg} / \mathrm{ha}$ for the individual rice growers, which compared favourably with the yield level of $4,250 \mathrm{~kg} / \mathrm{ha}$ for the N.I.B. tenants who enjoy much higher inputs.

'The estimates of the bags of paddy retained for home consumption were calculated as follows. Individual rice growers reported that they had sold three-quarters of their paddy harvest, and it was assumed that the remaining quarter was consumed. N.I.B. tenants (non-resident and resident) reported that they handed over $70 \%$ and $85 \%$ respectively of their produce to the scheme management. On the basis of Houtman's findings, it was assumed that one-third of the quantity of paddy retained was ultimately used for home consumption, the other two-thirds being used for payment-in-kind to agricultural labourers and for sales in local markets (Houtman, 1981: Table 14 and 34).

${ }^{n}$ It was assumed that $2600 \mathrm{KCal} .(10,870 \mathrm{KJ})$ are required per consumption unit daily, $80 \%$ of daily energy intake to be provided by cereals. 
and non-rice growers, on the other hand, a consumption period of only 2.5 months was covered. Disregarding these differences in food availability between groups and between individual farmers it is clear that households in the Kano Plain had to buy foods during the larger part of the year to meet their consumption needs and depended on incomes earned outside the subsistence sector.

\section{Food Consumption}

The staple food of the local population consists of cereals, maize in particular. The basic dishes are nyuka and kuon. Nyuka is a thin porridge, prepared from maize flour or a mixture of different flours and water with milk and sugar as optional ingredients. The dish is served at breakfast, as a snack in between meals and sometimes as a drink taken with lunch or supper. Kuon is the common dish, eaten at lunch and supper. It is a solid paste, usually consisting of maize flour, which is prepared by adding the flour to boiling water. Kuon is nearly always eaten in combination with a side-dish of a more liquid nature which is usually prepared using vegetables and fish, but may sometimes contain chicken, eggs or legumes.

The estimated average energy intake per consumption unit does not compare unfavourably with the figure of $2600 \mathrm{kcal}(10,870 \mathrm{KJ})$ per day recommended by FAO/WHO (Table IV). However, the intake levels differed considerably between the four study groups. The lowest energy intake level was found among the category of resident tenants. The highest figures, in contrast, were reached by the non-resident tenants and the individual rice growers. The contribution of rice to the energy intake proved to be very low among the rural population of the Kano Plain; only among the resident tenants did rice account for more than $10 \%$ of the energy intake.

The above mentioned averages, however, conceal large individual variations. A considerable number of compounds realized less than 80 per cent of the WHOnorm (Figure 2). This applies to 26 and 36 per cent of the compounds, belonging to the groups of non-resident tenants and individual rice growers. The two other categories were in an even more unfavourable position, particularly the resident tenants with almost half of the compounds below 80 per cent of the norm.

The above estimates pertain to compounds and disregard possible differences in food intake between family members within the same compound. Table V presents

TABLE IV

Food consumption among rice farmers in West Kenya (Compound estmate: Average intake per consumption unit (CU))

\begin{tabular}{lccccc}
\hline & $\begin{array}{c}\text { Non- } \\
\text { Rice } \\
\text { Growers } \\
(\mathrm{N}=134)\end{array}$ & $\begin{array}{c}\text { Individual } \\
\text { Rice } \\
\text { Growers } \\
(\mathrm{N}=54)\end{array}$ & $\begin{array}{c}\text { Non- } \\
\text { Resident } \\
\text { Tenants } \\
(\mathrm{N}=64)\end{array}$ & $\begin{array}{c}\text { Resident } \\
\text { Tenants }\end{array}$ & Total \\
$(\mathrm{N}=83)$ & $(\mathrm{N}=335)$ \\
\hline $\begin{array}{l}\text { Gr. Protein/CU } \\
\mathrm{KJ} / \mathrm{CU}^{\mathrm{a}}\end{array}$ & 84 & 95 & 94 & 84 & 88 \\
$\begin{array}{l}\text { Contribution of Rice to } \\
\text { Energy Intake }(\%)\end{array}$ & 10,835 & 11,566 & 11,207 & 10,425 & 10,922 \\
\hline
\end{tabular}

aWHO recommendations: $10,870 \mathrm{KJ}(2600 \mathrm{kcal}) /$ consumption unit 
FIGURE 2 Energy intake among rice farmers in West Kenya

(\% compounds with members realizing ony $80 \%$ of requirements or less)

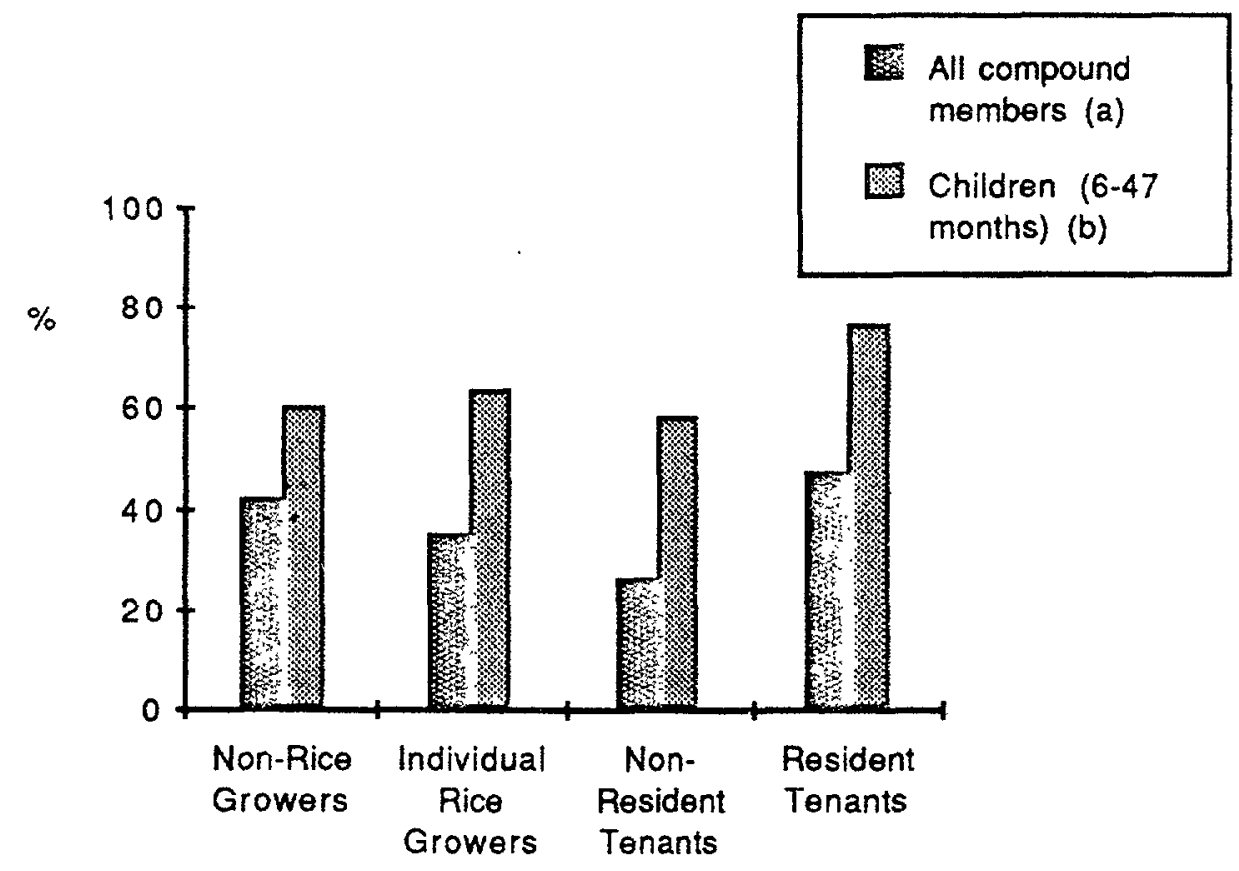

a) calculated per consumption unit (compound estimate)

b) calculated per $\mathrm{kg}$ body weight (individual estimate)

the results of the 24-hour recall of food intake among children aged 6-47 months. The average energy intake among this age group was $650 \mathrm{kcal} .(2720 \mathrm{KJ})$. Taking body-weight into account, this amounted to only 75 per cent of requirements which is low compared with the average energy intake level calculated on a compound basis (see Table IV) . The intake levels of energy, protein and nutrients among the children of the resident tenants were generally lower than those of the other groups. This group also had the largest proportion (three-quarters) of children who received less than 80 per cent of the recommended energy intake per kilogram body weight (Figure 2). Among the remaining groups, this proportion was less, although more than half the children still did not reach the recommended level, and there is little difference between the three groups in this respect.

tWhereas on a cumpound basis, the required energy intake was realized by $45 \%$ of the compounds, this compares with only $20 \%$ of the children realizing the recommended energy intake $\mathrm{kg}$ body weight while a much larger group of children consumed less than $80 \%$ and even less than $60 \%$ of the recommended level. Although it is possible that this discrepancy is the result of the different recall methods, more likely it reflects genuine diffences in consumption between aduits and children, because the bulky adult diet is not particularly well adapted to meet the needs of young children. 
TABLE V

Average intake of energy and nutrients by children of rice farmers in West Kenya (individual estimate for children aged 6-47 months)

\begin{tabular}{lccccc}
\hline & $\begin{array}{c}\text { Non- } \\
\text { Rice } \\
\text { Growers } \\
(\mathrm{N}=116)\end{array}$ & $\begin{array}{c}\text { Individual } \\
\text { Rice } \\
\text { Growers } \\
(\mathrm{N}=57)\end{array}$ & $\begin{array}{c}\text { Non- } \\
\text { Resident } \\
\text { Tenants } \\
(\mathrm{N}=80)\end{array}$ & $\begin{array}{c}\text { Resident } \\
\text { Tenants }\end{array}$ & Total \\
& $(\mathrm{N}=64)$ & $(\mathrm{N}=317)$ \\
\hline Energy (KJ) & 2750 & 2859 & 2905 & 2307 & 2721 \\
Protein (g) & 18.1 & 20.6 & 20.5 & 15.4 & 18.6 \\
Calcium (mg) & 244 & 408 & 334 & 252 & 298 \\
Iron (mg) & 4.5 & 4.8 & 5.1 & 3.9 & 4.6 \\
\hline
\end{tabular}

\section{Nutritional Status}

Adverse economic conditions first and foremost affect the vulnerable groups in society. In the case of nutrition, adverse conditions are particularly reflected in the status of young children, namely children under five years of age.

With respect to height-for-age, the main long-term nutritional indicator, the children of the resident tenants distinctly showed the least favourable-level of attained growth of all study groups. This difference is evinced by a lower average height-for-age (Figure 3), as well as a greater incidence of stunting (Figure 4). The height-for-age values of the children in the other three study conditions proved more favourable and differed little among each other.

Weight-for-height indicates the degree of wasting and recent nutritional condition. When comparing the various study groups, one difference stands out: the weight-for-height level was more favourable among the children of the nonresident tenants. The average weight-for-height was relatively high while simultaneously no wasted children ( $\mathrm{W}-\mathrm{H}<80$ ) were found among this group (Figures 3 and 4). Among the three other groups the percentage of wasted children varied

FIGURE 3 Anthropometry of children of rice farmers in West Kenya (Averages; children aged 6-47 months)

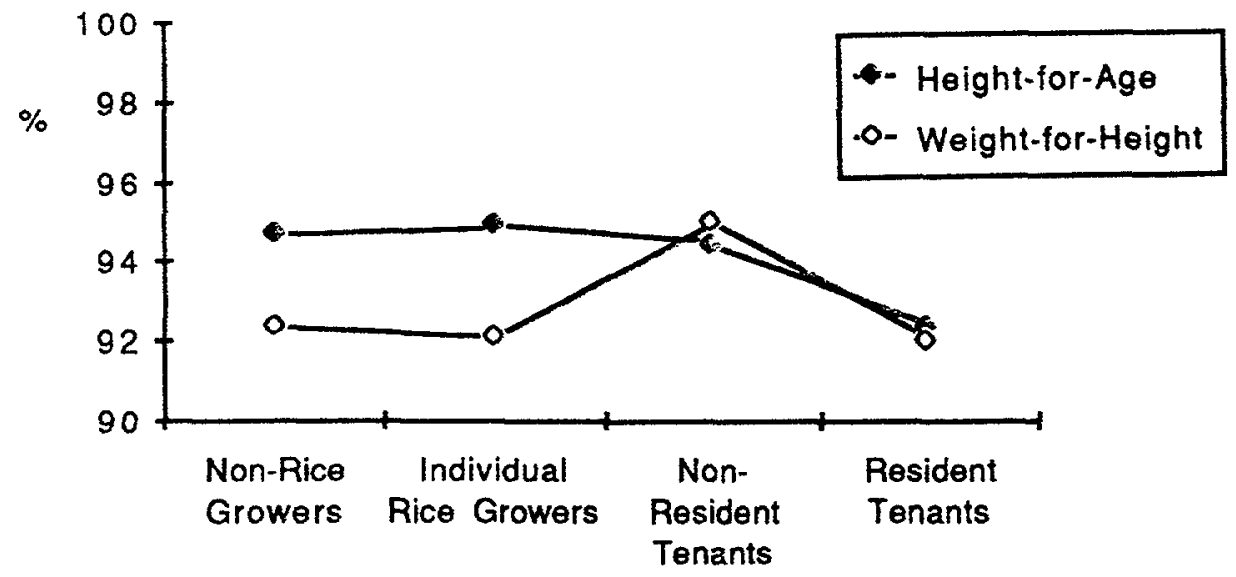


FIGURE 4 Anthropometry of children of rice farmers in West Kenya (\% below critical values of $\mathrm{H}-\mathrm{A}$ and $\mathrm{W}-\mathrm{H}$; children aged 6-47 months)

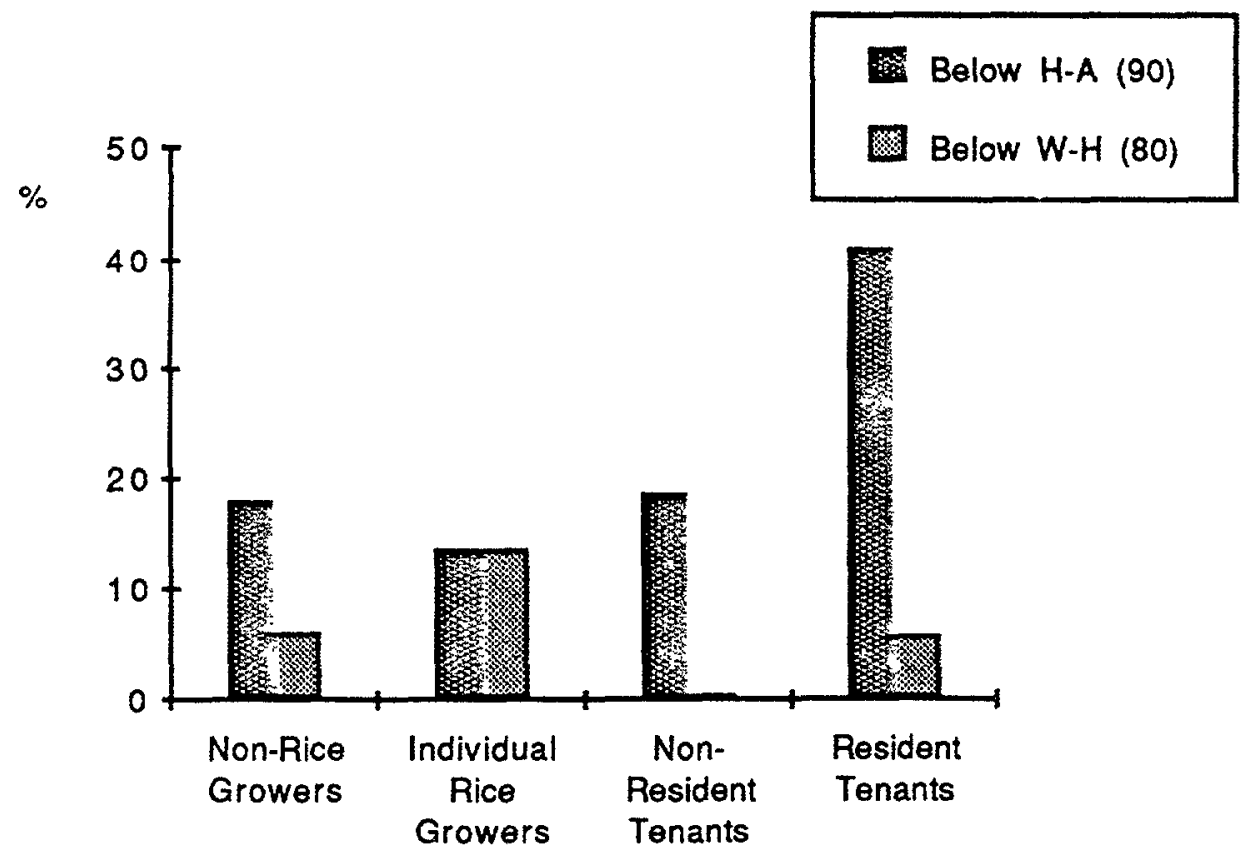

FIGURE 5 Weight-for-age of children of rice farmers in West Kenya (\% below critical value of W-A (80); children aged 6-47 months)

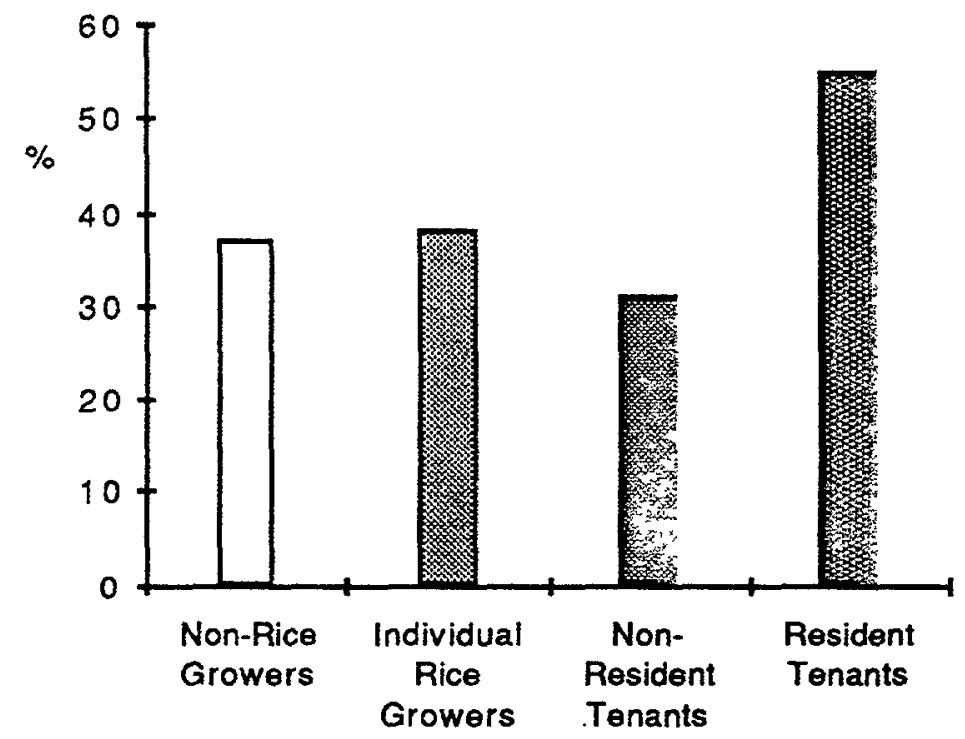


between 5 and $15 \%$. The variations in weight-for-height are not the result of differences in morbidity; at least no differences were found between the four study groups with respect to the incidence of diarrhoea and vomiting during the day prior to the home visit.

Weight-for-age, as general indicator of malnutrition, reveals that the highest incidence of undernutrition occurs among the children of the resident-tenants (Figure 5). On the other hand, undernutrition occurs least among the children of the non-residents. ${ }^{\dagger}$

\section{DISCUSSION}

In Kenya, with its limited land resources, the introduction of irrigated agriculture is regarded as one of the important agro-technological measures to boost production in the agricultural sector. The transition from rainfed to irrigated production within the smallholder sector not only implies changes in agricultural techniques and farm management practices but also results in different patterns of income generation and food supply, particularly when commercial crops are introduced in the cropping pattern. Likewise, the introduction of large-scale irrigated rice cultivation and the expansion of smallholder paddy cultivation have led to a significant transition in smallholder agriculture in the Kano Plain with many farm families becoming dependent on the sale of rice to secure a living.

The four population groups in the study reflect different degrees of participation in, and dependence on irrigated cultivation. At one extreme, the non-rice growers combine rainfed food crop cultivation with livestock rearing and their production activities are mainly based on traditional agricultural techniques and management practices. At the other extreme, the farming practices and the way of life of the resident tenants at the N.I.B. schemes have been radically changed. These farmers depend to a very large extent on the income from cash crop cultivation, and no longer are able to run their farms according to their own insights but have to follow farm management practices determined by the N.I.B. staff.

No attempt was made to arrive at a single monetary estimate of household income, but it is clear that important differences exist between the resource base of the various study groups. The resident tenants have access to few economic resources other than the production of commercial crops. This in contrast to the individual rice growers and non-resident tenants, who combine paddy cultivation with rainfed food cultivation, livestock keeping, and income from off-farm employment. Smallholders not cultivating rice take an intermediate position but still have a relatively more varied resource base than the resident tenants.

The resident tenants secured the lowest food production for home consumption and had the lowest average energy intake per consumption unit. The children belonging to this group appeared to have the most unfavourable food intake levels and also showed a higher incidence of stunting compared to those of the other study groups. The differences among the other groups are much smaller, although the nutritional status of the children of the non-resident tenants prove to be somewhat more favourable than that of the children of the individual rice growers and of the non-rice growers.

II may be noted that the observed variations in nutrition between the young children of the different study groups apply to the older children, namely, those in the age group of 4 to 10 years (Niemeijer et al. 1985: 106-109). 
The observed differences in nutrition between the four groups are related to the diversity of available resources. The farmers with a narrow resource base, the nonrice growers and, in particular, the resident tenants have the poorest nutritional situation. More favourable nutritional conditions exist among those smallholders having access to a wider range of resources including involvement in rainfed cropping for family subsistence as well as irrigated cash crop cultivation. This particularly applies to the category of non-resident tenants.

Other factors offer no alternative explanations for the findings. There were no differences in health conditions and the often heard suggestion that the farm families at the schemes eat only rice and therefore have an unbalanced diet was not confirmed. Rice is primarily produced for cash purposes, and only small quantities are consumed in addition to the main staple food, maize. Korte (1969) reported similar observations among the smallholder rice cultivators at the Mwea-Tebere irrigation schemes in Central Province.

Differences in (farm) cash income also do not offer an explanation. The N.I.B. tenants receive cash incomes in the order of several thousands of shillings per year. Moreover such income levels are highest among the category of resident tenants because they sell a larger quantity of their paddy output. However, this income does not compensate for the lack of other resources, either subsistence agriculture, livestock rearing or off-farm employment, or it is insufficiently allocated to purchase the necessary food.

Evidently it is not possible to draw one single conclusion about the nutritional consequences of participation in irrigated rice cultivation. The group with the most favourable nutritional condition and the one with the least favourable results are both tenants at the large irrigation schemes. Apparently, participation in rice cultivation has a negative impact on nutrition and results in a larger number of families with nutritional problems in the event that rice cultivation provides the family's sole means of existence. The assumption that the livelihood of rural families can be fully covered by this type of cash farming appears not to be valid as convincingly shown by the unfavourable nutritional conditions among the resident tenants. However, it cannot be maintained that participation in rice cultivation, as such, has detrimental nutritional effects. Only the group who are mainly dependent on their plots at the large irrigation schemes show symptoms of severe nutritional stress.

\section{ACKNOWLEDGEMENTS}

The research reported here was made possible through the co-operation of the Food and Nutrition Planning Unit of the Ministry of Planning and National Development, Nairobi and the African Studies Centre, Leiden; and was funded by the Netherlands Ministry of Development Co-operation. The authors are grateful for the assistance and comments of Luke Wasonga and Henk Meilink.

\section{REFERENCES}

FAO (1982) Integrating Nutrition into Agricultural and Kural Development Projects: A Manual. Food and Agriculture Organization, Rome.

FAO/WHO (1974) Handbook on Human Nutritional Requirements. Food and Agriculture Organization, Rome.

Fleuret $\mathrm{P}$ and A. Fleuret (1980). Nutrition, Consumption and Agricultural Change. Human Organization, 39, 250-260.

Houtman, C.B. (1981). Report of Agro-Economic Studies in the Ahero and West Kano Pilot Irrigation Schemes. IRDP Report No. 34, Nairobi. 
Jelliffe, D.B. (1966). The Assessment of the Nutrittonal Status of the Community. World Health Otganization, Geneva.

Kennedy, E.T. and P. Pinstrup-Andersen (1983). Nutrition-Related Policies and Programs: Past Performances and Research Needs. International Food Policy Research Institute, Washington, D.C.

Kliest, T. (1984). The Agricultural Structure of the Lower Kano Plain. Ministry of Planning and National Development/African Studies Centre. Food and Nutrition Studies Programme, Report No. 4. Nairobi/Leiden.

Kliest, T. (1985). Regional and Seasonal Food Problems in Kenya. Ministry of Planning and National Development/African Studies Centre. Food and Nutrition Studies Programme, Report No. 10. Nairobi/Leiden.

Korte, R. (1969). The Nutritional and Health Status of the People Living on the Mwea-Tebere Irrigation Settlement. In H. Kraut and H.D. Cremer (Eds) Investigations into Health and Nutrition in East Africa. IFO Institut fur Wirtschaftsforschung, Afrika Studien No. 42. Munich.

Lunven, P. (1982). The Nutritional Consequences of Agricultural and Rural Development Projects. Food and Nutrtion Bulletin, 4, 17-22.

McCarthy, F. and W. Mwangi (1979). Kenya Agriculture: Towards 2000. Ministry of Economic Planning and Community Affairs, Nairobi.

Mwangi, M. (1981). Implications of "Agriculture 2000" to Present Planning. In S.E. Migot Adholla and J.A. Nkinyangi (Eds) Proceedings of a Workshop on Food and Nutrition Planning in Kenya, Pp. 98-107. Ministry of Economic Planning and Development, Nairobi.

NIB (1981). South Kano Irrigation Scheme Feasibility Study. Vol I: Main Report: Vol II: Annex 3.7.8, National Irrigation Board/Agrar- und Hydrotechnik, Nairobi/Essen.

NIB (1982). Annual Report and Accounts, 1979-1980. National Irrigation Board, Nairobi.

Niemeijer, R.. M. Geuns, T. Kliest, V. Ogonda and J. Hoorweg (1985). Nutritional Aspects of Rice Cultivation in Nyanza Province, Kenya. Ministry of Planning and National Development/African Studies Centre, Food and Nutrition Studies Programme. Report No. 14. Nairobi/Leiden.

OAU (1981). The Lagos Plan of Action for the Economic Development of Africa. Organization of African Unity, Addis Abbeba.

Pacey, A. and P. Payne (Eds) (1985). Agricultural Development and Nutrition, Hutchinson, London.

Platt, B.S. (1962) Tables of Representative Values of Foods commonly used in Tropical Countries (revised ed.). Medical Research Council, special report 302. HMSO: London.

Republic of Kenya (1984). Development Plan 1984-1988. Government Printer, Nairobi.

Ruigu, G.M. (1987). Large-Scale Irrigation Development in Kenya: Past Performance and Future Prospects. Ministry of Planning and National Development/African Studies Centre. Food and Nutrition Studies Programme. Report No. 23. Nairobi/Leiden.

Senga, W., R. Faruqee and B. Ateng (1981) Population Growth and Agricultural Development in Kenya. Institute for Development Studies, Occasional Paper No. 40. Nairobi.

Steenbergen, W. van, J. Kusin, M. van Rens, K. de With and A. Jansen (1984). Lactation Performance. In J.K. van Ginneken and A.S. Muller (Eds) Maternal and Child Health in Rural Kenya. Pp. 153166. Croom Heim, London.

Sterkenburg, J.J.. J. Brandt and G.G. van Beinum (1982). Rural Housing Conditions in Kisumu District, Kenya. Department of Geography of Developing Countries, University of Utrech/Housing Research and Development Unit, University of Nairobi. Utrecht.

WHO (1983). Measuring Change in Nutritional Status: Guidelines for Assessing the Nutritional Impact of Supplementary Feeding Programmes for Vulnerable Groups. World Health Organization, Geneva.

World Bank (1981). Accelerated Development in Sub-Saharan Africa: An Agenda for Action. World Bank, Washington D.C.

World Bank (1983). Kenya, Growth and Structural Change. World Bank, Washington D.C. 